ISSN 1678-3921

Journal homepage: www.embrapa.br/pab

For manuscript submission and journal contents, access: www.scielo.br/pab
Arthur Inácio Saldanha Xavier ${ }^{(1)}$ (iD, Alessandro Porporatti Arbage(1) (iD), Michel Rocha da Silva ${ }^{(1)}$ (D), Giovana Ghisleni Ribas(1) (iD, Lorenzo Dalcin Meus ${ }^{(1)}$ (D), Gionei Alves de Assis dos Santos (2) (iD, Nereu Augusto Streck ${ }^{(1 \bowtie)}$ (D) and Alencar Junior Zanon(1) (DD

(1) Universidade Federal de Santa Maria, Avenida Roraima, ํo 1.000, Cidade Universitária, Camobi, CEP 97105-900 Santa Maria, RS, Brazil.

E-mail: arthurisxavier@gmail.com, aparbage@yahoo.com.br, michelrs@live.com, giovana.ghisleni@hotmail.com lorenzo_meus@hotmail.com, nstreck2@yahoo.com.br, alencarzanon@hotmail.com

(2) Instituto Rio Grandense do Arroz, Rua Appel, no 475, Centro, CEP 97015-030 Santa Maria, RS, Brazil.

E-mail: gionei-santos@irga.rs.gov.br

$\bowtie$ Corresponding author

Received

May 27, 2020

Accepted

November 25, 2020

How to cite

XAVIER, A.I.S.; ARBAGE, A.P.; SILVA, M.R. da; RIBAS, G.G.; MEUS, L.D.; SANTOS,

G.A. de A. dos; STRECK, N.A.; ZANON, A.J. Economic and productive analysis of irrigated rice crops using a multicase study. Pesquisa Agropecuária Brasileira, v.56, e02037, 2021. DOI: https://doi.org/10.1590/S1678-3921. pab2021.v56.02037.

\section{Economic and productive analysis of irrigated rice crops using a multicase study}

\begin{abstract}
The objective of this work was to evaluate the relationship between grain yield and production costs of flood-irrigated rice (Oryza sativa) in the state of Rio Grande do Sul, Brazil, in order to determine the yield range that maximizes the profit of farmers. There are estimations pointing out that the yield range that maximizes the profit for farmers is about 75 and $85 \%$ of the yield potential; however, this still needs to be validated for irrigated rice in Brazil. To validate these values, a technical and economic monitoring was carried out for eight farmers of irrigated rice, whose production costs were measured and compared with the mean yield and the percentage of potential yield achieved. To determine the potential yield of each crop, SimulArroz, a process-based model developed for the simulation of rice growth and yield in the South of Brazil, was used. The grain yield achieved by the farmers ranged from 6.3 to $11.0 \mathrm{Mg} \mathrm{ha}^{-1}$ (48 to $83 \%$ of the potential yield), costs ranged from $\mathrm{R} \$ 4,197.00 \mathrm{ha}^{-1}$ to $\mathrm{R} \$ 6,227.00 \mathrm{ha}^{-1}$, and profit ranged from $\mathrm{R} \$-52.00 \mathrm{ha}^{-1}$ to $\mathrm{R} \$ 3,599.00 \mathrm{ha}^{-1}$. Farmers who reach between 69 and $83 \%$ of yield potential achieve the highest profitability. The investment planning based on the yield potential calculated by the SimulArroz model can be efficiently adopted for irrigated rice crops.
\end{abstract}

Index terms: Oryza sativa, production costs, profitability, yield potential.

\section{Análise econômico-produtiva de lavouras de arroz irrigado por meio de um estudo multicasos}

Resumo - O objetivo deste trabalho foi avaliar a relação entre a produtividade de grãos e os custos de produção de lavouras de arroz (Oryza sativa) irrigado por inundação, no estado do Rio Grande do Sul, Brasil, para determinar a faixa de produtividade que maximiza o lucro do produtor. Existem estimativas de que a faixa de produtividade que maximiza o lucro para os agricultores é de cerca de 75 a $85 \%$ do potencial de produtividade; porém, isso ainda precisa ser validado para a cultura do arroz irrigado no Brasil. Para validar esses valores, foi realizado um acompanhamento técnico-econômico para oito produtores de arroz irrigado, cujos custos de produção foram determinados e comparados com a produtividade média e a percentagem da produtividade potencial atingida. Para determinar o potencial produtivo de cada lavoura, utilizou-se o SimulArroz, um modelo, baseado em processos, desenvolvido para a simulação do crescimento e da produtividade de arroz no Sul do Brasil. As produtividades atingidas pelos produtores variaram de 6,3 a $11,0 \mathrm{Mg} \mathrm{ha}^{-1}$ ( 48 a $83 \%$ do potencial de produtividade), os custos variaram de $\mathrm{R} \$ 4.197,00 \mathrm{ha}^{-1}$ a $\mathrm{R} \$ 6.227,00 \mathrm{ha}^{-1}$, e o lucro variou de $\mathrm{R} \$-52,00 \mathrm{ha}^{-1}$ a $\mathrm{R} \$ 3.599,00 \mathrm{ha}^{-1}$. Produtores que atingem entre 69 e $83 \%$ do potencial produtivo alcançam maior lucratividade. O planejamento de investimento com base no potencial produtivo, calculado pelo modelo SimulArroz, pode ser adotado eficazmente nas lavouras de arroz irrigado.

Termos para indexação: Oryza sativa, custos de produção, lucratividade, potencial produtivo. 


\section{Introduction}

Rice (Oryza sativa L.) is the staple food for half of people worldwide, playing a key role for world food security (Deng et al., 2019). To feed nine billion people by 2050 (OECD-FAO..., 2018), food production may have to be increased by more than $50 \%$, especially staple food for low-income people (Ittersum et al., 2013). This production increase can be achieved either by expanding the cropping area or by incrementing the crop yields (Marin et al., 2016). The latter choice is preferred because it is more sustainable in the long term, since new areas, in general, have fragile ecosystems (Lobell et al., 2009; Ittersum et al., 2013). However, it is important to determine not only the maximum attainable yield, but also the most profitable one, which is the main information that farmers chose to decide which rice management they will use.

Outside the Asian continent, Brazil is the largest rice producer, from which Rio Grande do Sul (RS) state is the country's largest producer, accounting for $70 \%$ of Brazilian rice production, covering a production area of about one million hectares (Usda, 2019). Although grain yield has been increasing in recent years (Acompanhamento..., 2018), there is a lack of economic gains for rice farmers due to the rising production costs and falling prices (Irga, 2019). There are three main causes for this financial imbalance, as follows: farming inputs, such as fertilizers, pesticides, and oil, which are mainly determined by global market, and the rice price that is mainly determined by domestic market (Arbage, 2012); the reduction of rice consumption per capita due to the increasing purchase power of Brazilian population (IBGE, 2009), and the emergence of close substitutes to rice; and the competition with other Mercosur countries, such as Paraguay and Argentina, both with lower rice production costs. These factors demanded an average rice production of $8.5 \mathrm{Mg} \mathrm{ha}^{-1}$ from the farmers, to equalize the incomes and costs in the last five years (Irga, 2017). Unfortunately, in this same period, the average rice yield in RS was only 7.6 $\mathrm{Mg} \mathrm{ha}^{-1}$ (Usda, 2019). This chaotic scenario is a rationale to search for a better understanding and to look for possible solutions aiming to maintain rice production sustainable in RS.

To enhance economic and environmental sustainability, it is necessary that researchers, extension programs, and farmers work together to identify the key factors which combine maximum yield with higher profits and lower environmental impacts (Cassman et al., 2003). The yield that maximizes profit has been referred to as exploitable yield (Ittersum et al., 2013). Some theoretical studies show that the best profit for farmers is about 75 and $85 \%$ of the yield potential (Cassman et al., 2003; Lobell et al., 2009; Grassini et al., 2015; Fischer, 2015); however, those estimates should to be validated for each farming system and country based on local data. It is not known which yield level fits better to maximize profit for irrigated rice in Brazil. Hence, it is necessary to validate the impact of farmer's management on the yield and economics.

The objective of this work was to evaluate the relationship between grain yield and production costs of flood-irrigated rice in the state of Rio Grande do Sul, Brazil, in order to determine the yield range that maximizes the farmers' profit.

\section{Materials and Methods}

The research was carried out in flooded rice fields, located in the Região Central of Rio Grande do Sul (RS) state, Brazil. This region is representative of flooded rice production systems in RS, for its soils, management practices, yield levels, and farm sizes varying from 20 up to 500 hectares. From a data set (184 surveys) taken during three growing seasons (2014/2015, 2015/2016, and 2016/2017), eight farmers were selected and surveyed. During the 2017/2018 growing season, they were surveyed again for the following four characteristics: plentiful agreement to cooperate with truth data on all the economic information asked; production scale; average yield from the last three years; and crop management.

A technical and economic monitoring of information on the inputs, machinery, and labor was performed during the 2017/2018 growing season in the eight farms. Taxes, interests on financing and lease were set out. Besides these information, each farmer's property was analyzed, during the growing season, to characterize and collect additional information, and to identify the main limiting factors to yield. The estimation cost was based on the Irga's methodology used to reach cost and profit per hectare for irrigated rice in RS (Irga, 2017).

To analyze the data, the rice management practices used in the farms were divided into nine phases: soil preparation, seeding, dressing fertilization, weed control, pest and disease control, water management, 
harvest and labor, taxes, interests on financing, and land cost (Figure 1). For each phase, the cost per hour and the number of working hours per hectare were calculated. Machine and input values were obtained from market and labor costs, according to each farm situation. To compose the actual machinery value, the new value of each machine was obtained from the market, as well as the residual value, lifetime, and the working hours per year. The fuel consumption and the operating speed were obtained from the technical and economic monitoring. The main prices and equations used to calculate the costs were based on Irga (2017).

To set the maximum attainable yield, the methodology proposed by the Global Yield Gap Atlas (GYGA, 2020) was used. The SimulArroz rice model (Rosa et al., 2015) was used to calculate the potential yield because of its widely validation for flooded rice grain yield in RS (Ribas et al., 2017, 2020). The SimulArroz is a process-based model which simulates the rice growth, development, and grain yield, in a day-time step. To calculate the yield potential by the SimulArroz, in the present study, the following inputs were used: meteorological data - daily solar radiation, and maximum and minimum temperatures $\left({ }^{\circ} \mathrm{C}\right)$; cultivars (IRGA 424 RI, Puitá Inta CL, Guri Inta CL, BRS 7 Taim, IRGA 426, and IRGA 417); sowing or emergency date; technology level of the field; ambient carbon dioxide concentration $\left(\mathrm{CO}_{2}\right)$; and plant density (Rosa et al., 2015). In the simulations for the present study, $\mathrm{CO}_{2}$ and plant density were set at $400 \mathrm{ppm}$

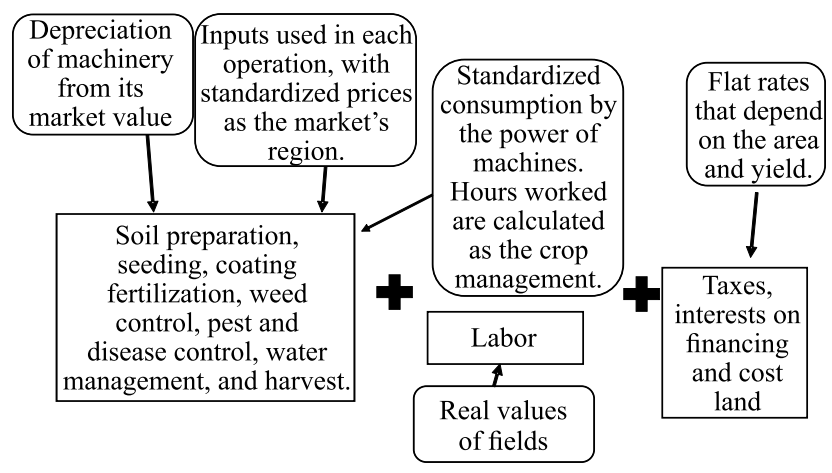

Figure 1. Framework for assessing the full values of each subdivision of the costs used in the analysis of eight floodirrigated rice (Oryza sativa) fields, which were sampled for the technical and economic analysis during the 2017/2018 growing season, in the state of Rio Grande do Sul, Brazil. and 200 plants $\mathrm{m}^{-2}$, respectively. The meteorological data used to run the model were daily minimum and maximum temperatures $\left({ }^{\circ} \mathrm{C}\right)$, and daily solar radiation (MJ m ${ }^{-2}$ per day) of the municipalities of Cachoeira do Sul and Santa Maria weather stations, that represent the climate of the study area and are located $84 \mathrm{~km}$ from each other. According to the Köppen-Geiger's classification, the climate of the region is Cfa, a humid subtropical, oceanic climate, without dry season, and with a hot summer (Alvares et al., 2013). The maximum and minimum mean annual temperatures are $25^{\circ} \mathrm{C}$ and $17^{\circ} \mathrm{C}$, respectively, and the annual mean solar radiation is $17 \mathrm{MJ} \mathrm{m}^{2}$ per day (Wrege et al., 2011). The model was run for short and medium maturity group cultivars (IRGA 424 RI, Puitá Inta CL, Guri Inta CL, BRS 7 Taim, IRGA 426, and IRGA 417), at the potential level that represents rice yield potential, with no influence of biotic and abiotic factors (Rosa et al., 2015). The dates used by the farmers for sowing ranged from October $7^{\text {th }}$ to November $29^{\text {th }}, 2017$. For each farmer's property, a weighted mean yield potential was estimated, that is, if one farmer sowed three cultivars, the potential yield was calculated with the potential yield of the three cultivars, and not only with the highest potential; this same procedure was used for the sowing dates. Actual yield was obtained from the farmer surveys, and then, the yield potential was calculated, as follows:

Yield potential $(\%)=$ Actual yield $\left(\mathrm{kg} \mathrm{ha}^{-1}\right) /$ Yield potential $\left(\mathrm{kg} \mathrm{ha}^{-1}\right)$

The analysis of the results was done by comparing the values of each farmer studied. Direct costs that directly influence yield are composed of the oil used in the preparation of soil, seed, fertilizers, and pesticides (Arbage, 2012).

\section{Results and Discussion}

High yield and profit variability were observed among the farmers. The average yield of farmers ranged from 6,369 to $11,000 \mathrm{~kg} \mathrm{ha}^{-1}$, and the production costs varied $\mathrm{R} \$ 2,040.00 \mathrm{ha}^{-1}$ between the lower and higher value (Table 1). Profit per hectare ranged from R $\$ 3,599.00 \mathrm{ha}^{-1}$ to a negative income ( $\$$-52.00 ha-1) (Figure 2); on the average profit, it was $\mathrm{R} \$ 966.00 \mathrm{ha}^{-1}$ higher than other economic profits found in the literature (Smith et al., 2011; Chang et al., 2017; Oliveira Neto, 2017). This fact can be explained by some reasons, as follows: there are farmers with higher production efficiency than the 
average one; labor costs are lower for the famers who have the rice production based on family labor; and the use of irrigation is moved by natural resource (gravity), which is less expensive than pumping irrigation.

The results showed that the combination of yield and efficiency in the use of resources are the key role to the sustainability of rice production. To better understand this relationship, the eight farmers were grouped into four groups (Figure 3). Two farmers who represent higher efficiency in the use of resources have farm sizes between 47 ha and 55.8 ha, and, at least two family members work in rice activity. The results for the farmers who have low to medium percentage of the yield potential, with good profitability, showed no relation between farm sizes (20 and 130 ha), but it displayed some difficulty of the farmers for the crop management, which are limiting them to achieve a greater yield. The farmers who attained high percentages of the yield potential, but with low efficiency in the use of resources, have properties between 77 and 524 ha, and only one family member working in it in an administrative way, but with little or no intervention in crop management. At last, there were farmers with very low percentages of yield gap, whose properties have size areas between 28 and

Table 1. Technical and economic characterization of eight flood-irrigated rice (Oryza sativa) fields evaluated during the 2017/2018 growing season, in the state of Rio Grande do Sul, Brazil ${ }^{(1)}$.

\begin{tabular}{lccccc}
\hline Farmer & City & $\begin{array}{c}\text { Area } \\
\text { (ha) }\end{array}$ & $\begin{array}{c}\text { Total } \\
\text { costs } \\
\left(\mathrm{R} \$ \mathrm{ha}^{-1}\right)\end{array}$ & $\begin{array}{c}\text { Grain } \\
\text { Yield } \\
\left(\mathrm{kg} \mathrm{ha}^{-1}\right)\end{array}$ & $\begin{array}{c}\text { Yield } \\
\text { potential } \\
(\%)\end{array}$ \\
\hline 1 & $\begin{array}{c}\text { São João do } \\
\text { Polesine (SJP) }\end{array}$ & 93 & 4,322 & 6,369 & 56 \\
2 & Santa Maria & 130 & 5,517 & 9,000 & 69 \\
3 & Restinga Seca & 28 & 4,197 & 6,518 & 48 \\
4 & Santa Maria & 77 & 4,747 & 7,807 & 72 \\
5 & SJP & 20 & 4,822 & 9,890 & 69 \\
6 & Cachoeira do Sul & 524 & 6,227 & 8,510 & 73 \\
7 & Santa Maria & 47 & 4,382 & 11,000 & 77 \\
8 & Agudo & 55.8 & 5,986 & 10,500 & 83 \\
\hline Mean & - & 66 & 4,785 & $8,754.9$ & 70 \\
\hline CV (\%) & - & 137 & 16 & 20 & 17 \\
\hline
\end{tabular}

${ }^{(1)}$ Taxes, interests on financing, and lease were not included in the total cost. The yield potential of rice was calculated with the SimulArroz model. CV, coefficient of variation.
93 ha, with one and two family members working in rice activity, respectively.

This information could lead to two hypotheses described for further in loco economic analysis. The first one relates to the fact that, in larger areas, it is more difficult to achieve a good management

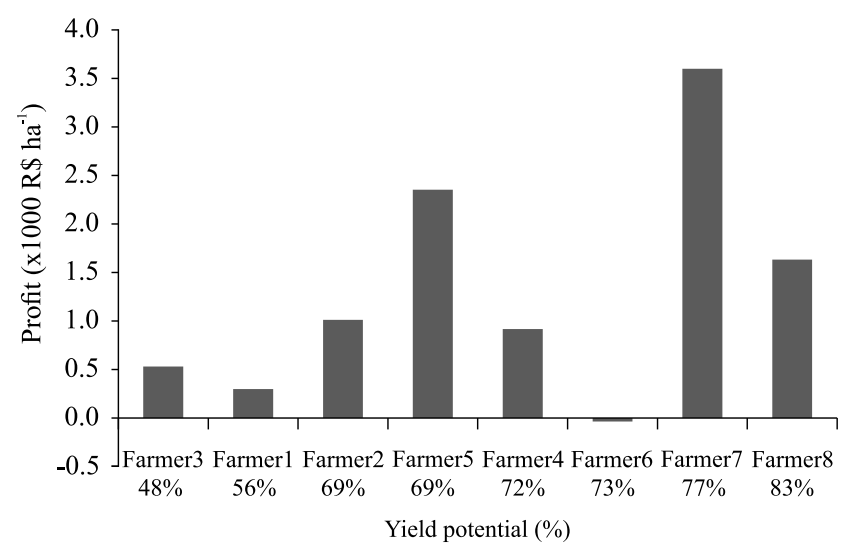

Figure 2. Profit per hectare versus rice (Oryza sativa) yield potential attained by farmers in eight flood-irrigated rice fields, in the 2017/2018 growing season, in the state of Rio Grande do Sul, Brazil.

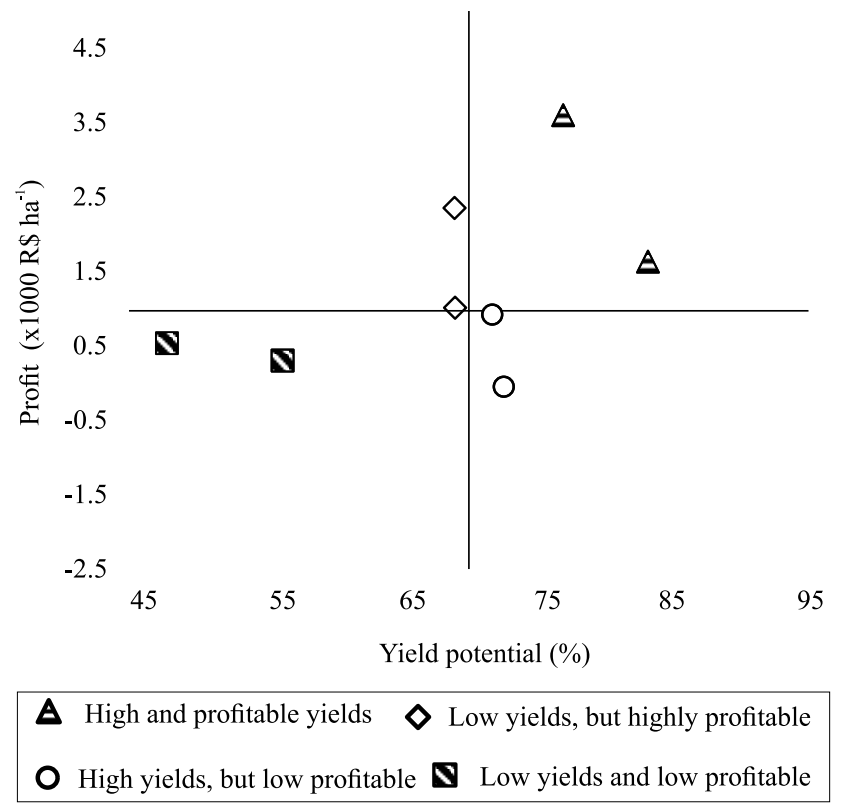

Figure 3. Profit of eight flood-irrigated rice (Oryza sativa) field samples versus rice yield potential attained by farmers, for the technical and economic analysis during the 2017/2018 growing season, in the state of Rio Grande do Sul, Brazil. 
and, consequently, it is more difficult to attain high efficiency in the rice production. The second hypothesis is that, in farms where there are more family members engaged in the production system, there are more efficiency because of the greater care and lower labor cost. Data interfering with the causes of the worst performing farmers are presented in Table 2. Cost is not the explanatory factor because, in both cases, it is lower than the general average. Yield, however, is the cause of poor performance, since it is up to $27 \%$ lower than the general average, in gross value, and with a large yield gap in relation to crop potential. This indicates that the percentage of the yield potential can be an important influence factor on the profitability (Fischer \& Connor, 2018).

The first and the third more profitable farms had more than $75 \%$ of the yield potential, which, according to the literature, is the range where the highest profitability is achieved (Lobell et al., 2009; Grassini et al., 2015). Production costs were less sensitive than yield to variation due to factors that increase grain yield, without causing cost increases (Figure 4). With similar amount of direct costs, a great variation was observed between the farmers' yield and profit, which suggests that the first step to increase the profit of less productive crops is to increase yield.

Farm yields tend to stagnate when they reach $75-85 \%$ of yield potential, which can be attributed to diminishing returns from investments in additional production inputs, and to effort as yields approach the potential yield ceiling (Grassini et al., 2011; Deng et al., 2019).
This was the case for the farmer 8 , who reached $83 \%$ of the yield potential; a reduction in the yield gap above this range yield may not be environmentally sustainable and, in most cases, does not justify the investment (Cassman et al., 2003; Grassini et al., 2011; Farmaha et al., 2015).

Labor force was the factor that most influenced the poor performance. For the farmer 7, this component had a low cost due to the almost exclusive use of family labor. However, for the farmer 6, labor force was very high because of the large number of fixedterm employees, which increases the production cost (Table 2). The use of the labor force is very costly and directly affects the cropping profitability (Smith et al., 2011; Chang et al., 2017).

Therefore, the result of the farmer 6 was the lack of management of the resources, that is, despite the high yield achieved in relation to the yield potential of that growing season, the farmer had to bear a very high cost (Figure 4). It is not enough, therefore, to have a high yield, since, if there is not an efficient use of the resources, the investment should be proportional to the yield potential of the crop (Mueller et al., 2012). It is important to consider that the farmer 6 was the one with the largest area under cultivation, and this causes greater difficulty in management.

The other important case was the farmer 7, who obtained the highest profitability (Figure 4), thus this case will be analyzed in comparison to the average. The contribution to this performance was yield, which reached $77 \%$ of the yield potential, included in the

Table 2. Variable production costs of eight flood-irrigated rice (Oryza sativa) fields sampled for the technical and economic analysis, during the 2017/2018 growing season, in the state of Rio Grande do Sul, Brazil.

\begin{tabular}{|c|c|c|c|c|c|c|}
\hline Farmer & $\begin{array}{l}\text { Coverage fertilizer } \\
\qquad\left(\mathrm{R} \$ \mathrm{ha}^{-1}\right)\end{array}$ & $\begin{array}{l}\text { Weeds } \\
\left(\mathrm{R} \$ \text { ha }^{-1}\right)\end{array}$ & $\begin{array}{c}\text { Insects and } \\
\text { diseases }\left(\mathrm{R} \$ \mathrm{ha}^{-1}\right)\end{array}$ & $\begin{array}{l}\text { Water management } \\
\qquad\left(\mathrm{R} \$ \mathrm{ha}^{-1}\right)\end{array}$ & $\begin{array}{l}\text { External labor }{ }^{(1)} \\
\qquad\left(\mathrm{R} \$ h^{-1}\right)\end{array}$ & $\begin{array}{l}\text { Profit } \\
\left(\mathrm{R} \$ \mathrm{ha}^{-1}\right)\end{array}$ \\
\hline 1 & 339.0 & 401.0 & 211.0 & 569.0 & 52.0 & 300.0 \\
\hline 2 & 529.0 & 488.0 & 201.0 & 721.0 & 204.0 & $1,014.0$ \\
\hline 3 & 326.0 & 405.0 & 123.0 & 238.0 & 185.0 & 532.0 \\
\hline 4 & 291.0 & 209.0 & 161.0 & 397.0 & 546.0 & 918.0 \\
\hline 5 & 384.0 & 414.0 & 118.0 & 672.0 & 100.0 & $2,354.0$ \\
\hline 6 & 517.0 & 548.0 & 209.0 & 513.0 & $1,500.0$ & -52.0 \\
\hline 7 & 451.0 & 166.0 & 63.0 & 298.0 & 51.0 & $3,599.0$ \\
\hline 8 & 320.0 & 265.0 & 235.0 & 418.0 & 917.0 & $1,633.0$ \\
\hline Mean & 394.6 & 362.0 & 165.1 & 478.2 & 444.3 & 966.0 \\
\hline CV (\%) & 24.0 & 37.0 & 36.0 & 36.0 & 117.0 & 94.0 \\
\hline
\end{tabular}

${ }^{(1)}$ Contracted, excluding family labor. $\mathrm{CV}$, coefficient of variation. 
margin that provides the highest economic income, according to the literature (Cassman et al., 2003; Arbage, 2012; Grassini et al., 2015). Gross yield was the highest among the studied farmers, which means a high technical efficiency and a high gross revenue. Little was spent on the external labor because it comes from family working, and water management cost is low because it is done by gravity, without pumping costs. The low cost of pest and disease management (Table 2) can be explained by the cultivars used which have a great rusticity and resistance to diseases (Ogoshi et al., 2018). As to weed management, the expense was significantly lower than the average because the field was already free of infestations. The cost that exceeded the average among the analyzed ones was that of the fertilization in coverage by the high dose of nitrogen, and the application of potassium chloride.

In summary, if you invest more in the factor that builds yield, fertilization, and in the other analyzed components, and if you work with low costs, avoiding waste because they are indirect in relation to yield. The best performance of farmer 7 is therefore explained by the high yield combined with the efficient management of the production factors. It was also observed that the variation of direct costs with a direct influence on yield, among farmers, is less significant than the variation of profitability and total costs between them and, as previously observed, the variation between yields is even greater. This shows that even though

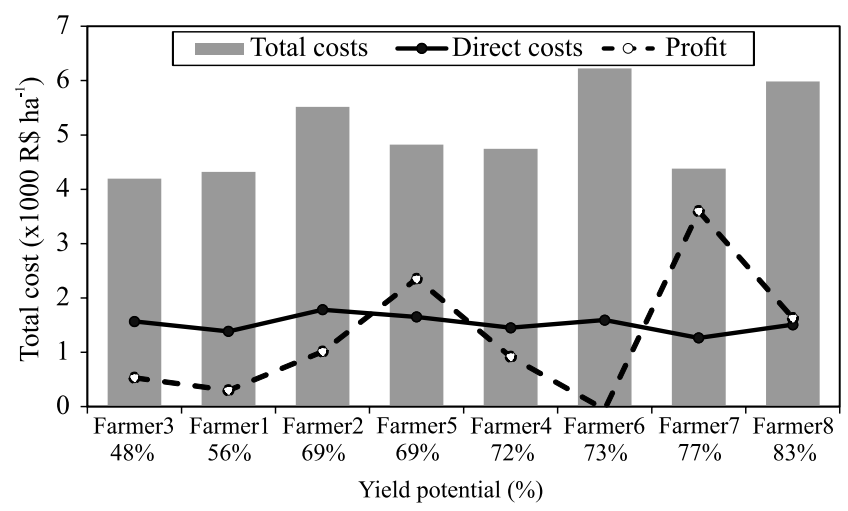

Figure 4. Total production cost versus rice (Oryza sativa) yield potential attained by farmers in eight flood-irrigated rice fields samples, for the technical and economic analysis during the 2017/2018 growing season, in the state of Rio Grande do Sul, Brazil. the impact of management differences is important for increasing yield, they were not cost-intensive.

The two farmers with the highest yields were those who spent least on weeds (Tables 1 and 2). And the farmers who invested the most in controlling weeds were the least productive and profitable. In fact, the occurrence of significant infestation by weeds was verified in the visits to these cultivations, which required investment. Weed control in the right moment favors the reduction of yield loss, and it increases the costs with control after an increased infestation (Mueller et al., 2012). In addition, the fertilizer costs of the most productive farmers was not higher than the others, which suggests that in the other cases there are factors limiting yield that prevent the full use of the fertilizer applied. The presented results, as well as the example of an analysis on the agronomic and administrative elements can be instruments for the construction of a methodology and the first step for further studies on the cultivation of rice and other agricultural crops.

\section{Conclusions}

1. The highest profits are obtained when the yield of flood-irrigated rice (Oryza sativa) attained ranges from 69 to $83 \%$ of the yield potential.

2. The closer the attained yield is to the yield potential, the higher is the crop profit for farmers.

\section{Acknowledgments}

To the FieldCrops team for their support; to Mara Grohs and Pablo Mazzuco de Souza, extensionists of the Instituto Rio Grandense do Arroz (Irga), for helping to find the farmers; to the Irga's consultant Jossana Ceolin Cera, for providing the meteorological information; and to all farmers who agreed to participate in the work, whose names cannot be described according to the agreement made with them.

\section{References}

ACOMPANHAMENTO DA SAFRA BRASILEIRA [DE] GRÃOS: safra 2017/18: sétimo levantamento, v.5, n.7, abr. 2018. Available at: <https:/www.conab.gov.br/info-agro/safras/graos/ boletim-da-safra-de-graos>. Accessed on: Oct. 12018. 
ALVARES, C.A.; STAPE, J.L.; SENTELHAS, P.C.; GONÇALVES, J.L. de M.; SPAROVEK, G. Köppen's climate classification map for Brazil. Meteorologische Zeitschrift, v.22, p.711-728, 2013. DOI: https://doi.org/10.1127/09412948/2013/0507.

ARBAGE, A.P. Fundamentos de economia rural. 2.ed. Chapecó: Argos, 2012.

CASSMAN, K.G.; DOBERMANN, A.; WALTERS, D.T.; YANG, H. Meeting cereal demand while protecting natural resources and improving environmental quality. Annual Review of Environment and Resources, v.28, p.315-358, 2003. DOI: https://doi.org/10.1146/annurev.energy.28.040202.122858.

CHANG, T.; TAKAHASHI, D.; YANG, C.-K. Profit efficiency analysis of rice production in Taiwan. China Agricultural Economic Review, v.9, p.32-47, 2017. DOI: https://doi.org/10.1108/ CAER-04-2016-0059.

DENG, N.; GRASSINI, P.; YANG, H.; HUANG, J.; CASSMAN, K.G.; PENG, S. Closing yield gaps for rice self-sufficiency in China. Nature Communications, v.10, art.1725, 2019. DOI: https://doi.org/10.1038/s41467-019-09447-9.

FARMAHA, B.S.; LOBELL, D.B.; BOONE, K.E.; CASSMAN, K.G.; YANG, H.S.; GRASSINI, P. Contribution of persistent factors to yield gaps in high-yield irrigated maize. Field Crops Research, v.186, p.124-132, 2015. DOI: https://doi.org/10.1016/j. fcr.2015.10.020.

FISCHER, R.A. Definitions and determination of crop yield, yield gaps, and of rates of change. Field Crops Research, v.182, p.9-18, 2015. DOI: https://doi.org/10.1016/j.fcr.2014.12.006.

FISCHER, R.A.; CONNOR, D.J. Issues for cropping and agricultural science in the next 20 years. Field Crops Research, v.222, p.121-142, 2018. DOI: https://doi.org/10.1016/j. fcr.2018.03.008.

GRASSINI, P.; THORBURN, J.; BURR, C.; CASSMAN K.G. High-yield irrigated maize in the Western U.S. Corn Belt: I. On-farm yield, yield potential, and impact of agronomic practices. Field Crops Research, v.120, p.142-150, 2011. DOI: https://doi.org/10.1016/j.fcr.2010.09.012.

GRASSINI, P.; VAN BUSSEL, L.G.J.; VAN WART, J.; WOLF, J.; CLAESSENS, L.; YANG, H.; BOOGAARD, H.; DE GROOT, H.; ITTERSUM, M.K. van; CASSMAN, K.G. How good is good enough? Data requirements for reliable crop yield simulations and yield-gap analysis. Field Crops Research, v.177, p.49-63, 2015. DOI: https://doi.org/10.1016/j.fcr.2015.03.004.

GYGA. Global Yield Gap Atlas. Available at: <http://www. yieldgap.org/>. Accessed on: Dec. 172020.

IBGE. Instituto Brasileiro de Geografia e Estatística. Pesquisa de Orçamentos Familiares. 2009. Available at: <http://www.ibge. gov.br/>. Accessed on: Sept. 102018.

IRGA. Instituto Rio Grandense do Arroz. Custo de produção médio ponderado do arroz irrigado do Rio Grande do Sul: safra 2017/18. Porto Alegre, 2017. Available at: <http://stirga2018admin.hml.rs.gov.br/upload/arquivos/201805/18160831-custo-120180115091236custo-2017-18.pdf>. Accessed on: Sept. 142018.
IRGA. Instituto Rio Grandense do Arroz. Série histórica de preços de arroz em casca. Porto Alegre, 2019. Available at: $<$ https://irga.rs.gov.br/mercado>. Accessed on: Nov. 272019.

ITTERSUM, M.K. van; CASSMAN, K.G.; GRASSINI, P.; WOLF, J.; TITTONELL, P.; HOCHMAN, Z. Yield gap analysis with local to global relevance - a review. Field Crops Research, v.143, p.4-17, 2013. DOI: https://doi.org/10.1016/j.fcr.2012.09.009.

LOBELL, D.B.; CASSMAN, K.G.; FIELD, C.B. Crop yield gaps: their importance, magnitudes and causes. Annual Review of Environment and Resources, v.34, p.179-204, 2009. DOI: https://doi.org/10.1146/annurev.environ.041008.093740.

MARIN, F.R.; MARTHA JR., G.B.; CASSMAN, K.G.; GRASSINI, P. Prospects for increasing sugarcane and bioethanol production on existing crop area in Brazil. BioScience, v.66, p.307-316, 2016. DOI: https://doi.org/10.1093/biosci/biw009.

MUELLER, N.D.; GERBER, J.S.; JOHNSTON, M.; RAY, D.K.; RAMANKUTTY, N.; FOLEY, J.A. Closing yield gaps through nutrient and water management. Nature, v.490, p.254-257, 2012. DOI: https://doi.org/10.1038/nature11420.

OECD-FAO Agricultural Outlook 20182027. Paris: OECD; Rome: FAO, 2018. Special focus: Middle East and North Afric. Available at: <http://www.agri-outlook.org/Agricultural-Outlook-2018. pdf $>$. Accessed on: Oct. 42018.

OGOSHI, C.; CARLOS, F.S.; UlGUIM, A.R.; ZANON, A.J.; BITTENCOURT, C.R.C.; ALMEIDA, R.D. Effectiveness of fungicides for rice blast control in lowland rice cropped in Brazil. Tropical and Subtropical Agroecosystems, v.21, p.505-511, 2018.

OLIVEIRA NETO, A.A. de (Org.). Evolução dos custos de produção e rentabilidade do arroz-irrigado gaúcho nos anossafra 2006/07 a 2016/17. Brasília: Conab, 2017. (Compêndio de estudos Conab, v.11).

RIBAS, G.G.; STRECK, N.A.; DUARTE JUNIOR, A.J.; NASCIMENTO, M.F. do; ZANON, A.J.; SILVA, M.R. da. Number of leaves and phenology of rice hybrids simulated by the SimulArroz model. Revista Brasileira de Engenharia Agrícola e Ambiental, v.21, p.221-226, 2017. DOI: https://doi.org/10.1590/1807-1929/agriambi.v21n4p221-226.

RIBAS, G.G.; STRECK, N.A.; DUARTE JUNIOR, A.J.; RIBEIRO, B.S.M.R.; PILECCO, I.B.; ROSSATO, I.G.; RICHTER, G.L.; BEXAIRA, K.P.; PEREIRA, V.F.; ZANON, A.J. An update of new flood-irrigated rice cultivars in the SimulArroz model. Pesquisa Agropecuária Brasileira, v.55, e00865, 2020. DOI: https://doi.org/10.1590/S1678-3921.pab2020.v55.00865.

ROSA, H.T.; WALTER, L.C.; STRECK, N.A.; DE CARLI, C.; RIBAS, G.G.; MARCHESAN, E. Simulação do crescimento e produtividade de arroz no Rio Grande do Sul pelo modelo SimulArroz. Revista Brasileira de Engenharia Agrícola e Ambiental, v.19, p.1159-1165, 2015. DOI: https://doi.org/10.1590/1807-1929/agriambi.v19n12p1159-1165.

SMITH, R.B.W.; GEMMA, M.; PALINISAMI, K. Profit based efficiency measures, with an application to rice production in Southern India. Journal of Agricultural Economics, v.62, p.340356, 2011. DOI: https://doi.org/10.1111/j.1477-9552.2010.00288.x. 
A.I.S. Xavier et al.

USDA. United States Department of Agriculture. Production, Supply and Distribution. Available at: <www.usda.gov/wps/ portal/usda/usdahome?navid=DATA_STATISTICS $>$. Accessed on: July 122019.
WREGE, M.S.; STEINMETZ, S.; REISSERJÚNIOR, C.; ALMEIDA, I.R. de. (Ed.). Atlas climático da Região Sul do Brasil: Estados do Paraná, Santa Catarina e Rio Grande do Sul. Pelotas: Embrapa Clima Temperado; Colombo: Embrapa Florestas, 2011. 333p. 